\title{
Is Electronic Access to Medical Records an Empowering and Patient- centered Initiative? - A Qualitative Contextual and Linguistic Analysis of Danish Electronic Record
}

\begin{abstract}
Political correctness demands a patient empowering and patient-centered approach to health care and today patients are increasingly involved in, and responsible for, their own health. Patients are potentially subjected to large amounts of health information and, in a Danish context, patients have recently gained easy electronic access to their hospital records. Access, which used to be by application, is now only a few clicks away. This initiative is praised as patient empowering and patient-centered even though the e-records are not written for patients, but are the working tool of health professionals. Thus, an expert language text, as it stands, has to function as patient information. In this article, we examine the language of the e-records with a view to determining potential lay-friendliness and thus patient-centeredness. We also discuss whether access, by definition, is a progressive initiative and whether patient empowerment is always the same as patient-centeredness.
\end{abstract}

\section{Keywords}

patient empowerment; patient-centeredness; health literacy; e-records; lay-friendliness

\section{Introduction and background}

Over the last decades, the discourse of the health-care systems in the Western world has changed from being characterised by a medical hegemony to a more patient-centered discourse. Consequently, in many health-care systems the doctor is no longer seen as an autonomous expert and a higher degree of patient involvement is called for. As a part of this discourse, the concept of patient empowerment is seen both as a way to be patient-centered (whether the patient wants empowerment or not) and as a goal in itself, in contrast with compliance as the goal for the medical hegemony (Olesen 2010 in Thorgaard et al. 2010: 319, Holmström/Röing 2009). This makes both patient-centeredness and patient empowerment buzzwords in present day health communication, used both separately and as synonyms (Vásquez et al. 2016, Holmström/Röing 2009, Cornwall/ Brock 2006).

In Denmark, both concepts are constantly referred to, particularly in the context of the health authorities (for example in Regionernes Sundheds-IT Organisation 2011, Danske Regioner 2015 and www.regioner.dk 2009). Emphasising patient-centeredness is presumably seen as politically correct in the health-care context. Concurrently with the increased involvement of patients, more written patient information has been published and made available. A Danish example is patients' recent access to electronic hospital records (e-records), hailed as a patient empowering and patient-centered initiative (in Regionernes Sundheds-IT Organisation (RSI): Strategi for ITunderstøttelse af Patient Empowerment 2011, among others). Access has been given in spite of the fact that this working tool of the medical experts (www.sundhed.dk 2015) may not be written

* Martha Monrad Hansen

affiliation

affiliation

marthamonrad@hotmail.com
Karen Korning Zethsen School of Communiation and Culture Aarhus University

kkz@cc.au.dk 
in a language understandable to most patients. Giving patients access to e-records means that this expert-language text has to function as patient information. It has never been studied whether the language of Danish e-records actually does function as patient information. Furthermore, it has never been investigated if the access to e-records is empowering and patient-centered in practice, or just discursively constructed as being so. The aim of this article is, therefore, to examine the language of the e-records with a view to determining potential lay-friendliness, patient-centeredness and patient empowerment.

\subsection{Readability as the first step to understandable, empowering and patient- centered information}

\section{Readability - a fundamental part of health literacy}

An Australian professor of public health, Don Nutbeam (2000), describes readability in connection with health literacy. He operationalises health literacy as a continuum with three levels (Nutbeam 2000: 265):

1. Functional health literacy where you can basically read, understand and act on health related information.

2. Interactive health literacy where you are also able to understand more collaborative and modern forms of health communication, e.g. on the Internet.

3. Critical health literacy where you are, moreover, able critically to evaluate health information and use the information to take control of your own health, illness and living conditions.

Nutbeam's continuum points out that even the basic level of functional health literacy requires a person to be able to read (and understand and act on) health-related information.

\section{Health literacy determines patient empowerment}

Nutbeam also makes clear that only if you reach the level of critical health literacy are you empowered as a patient (Nutbeam 2000). In other words, it is meaningless to talk about patient empowerment, and thus patient-centeredness, if the patient is not able to at least read and understand relevant health information (Nutbeam 2000: 264). Thus, Nutbeam links patient empowerment to health literacy: the greater the health literacy level, the greater the level of patient empowerment. He also links health literacy to empowerment in his definition of health literacy, which he wrote for the World Health Organisation (WHO), as follows (WHO 1998: 10):

Heath literacy represents the cognitive and social skills which determine the motivation and ability of individuals to gain access to, understand and use information in ways which promote and maintain good health. Health literacy implies the achievement of a level of knowledge, personal skills and confidence to take action to improve personal and community health by changing personal lifestyles and living conditions. Health literacy means more than being able to read pamphlets and successfully make appointments. By improving people's access to health information and their capacity to use it effectively, health literacy is critical to empowerment (our emphasis).

\section{The definition of patient empowerment}

The origin of patient empowerment is not found within health care, but in Paulo Freire's pedagogical theories from the 1960s and 1970s (Askehave/Zethsen 2010). Later, in the 1980s, the concept of empowerment was used as a management tool to obligate the employees to follow the company's management objectives (Olesen 2010). 
Like patient-centeredness, the concept of patient empowerment is interpreted in many different ways and is widely used and discussed (Strunck 2010, Holmström/Röing 2009, Vásquez et al. 2016). The fundamental meaning of the concept - and the word in itself - is to give someone power, which implies evening out the differences of power, control, ownership and competence to act between various stakeholders - in the context of health communication, often between patients and the health authorities (Strunck 2010: 147-180, Sundhedsstyrelsen 2005). Within health communication most definitions of empowerment (e.g. Rappaport (1987), and Funnell et al. (1991) in Vásquez et al. 2016; Rodwell (1996) and Ellis-Stoll/Popkess-Vawter (1998) in Holmström/Röing (2009); WHO (1998)), hold two main elements:

1. Evening out power, control, ownership and competence

2. The patient's application of power, control, ownership and competence

The evening out of power, control etc. dominates most definitions of empowerment. Rappaport states, in short, that empowerment is "the process by which people gain mastery over their affairs" (Rappaport 1987, in Vásquez et al. 2016: 910), which has become a seminal definition of empowerment. The definition by Rodwell also revolves around the evening out of power, control and so on, saying that empowerment is "a helping process, a partnership", "mutual decision making using resources, opportunities and authority, and freedom" and "to accept responsibility"[from the point of view of the patient] (Rodwell (1996) in Holmström/Röing 2009: 169). Ellis-Stoll/ Popkess-Vawter also focus on these characteristics, pointing out that empowerment consists of "mutual participation" and "individualized knowledge acquisition" [from the point of view of the practitioner] (Ellis-Stoll/Popkess-Vawter (1998) in Holmström/Röing 2009: 169). Funnell et al. especially focus on competences describing empowerment as having the nessecary "knowledge, skills, attitudes and self-awareness" (Funnell et al. (1991) in Vásquez 2016: 910).

The WHO accords with Rappaport in the question of evening out power, control and so on, saying that empowerment is "a process through which people gain greater control over decisions" (WHO 1998: 354) but adds "... and actions affecting their health" (WHO 1998: 354); and in this way also includes the element of the patients' application of power, control and so on. Similarily, Rodwell's definition adds that the patients' power, control etc. (resources, opportunities, authority and freedom) should be used "to make choices" and for "mutual decision making" (Rodwell (1996) in Holmström/Röing 2009: 169). Funnell et al. conceptualise the application of power by stating that the patient should have the knowledge, skills, attitudes and self-awareness "necessary to influence their own behaviour and that of others in order to improve the quality of their lives" (Funnell et al. 1991, in Vásquez 2016: 910).

However, the phrasings above concerning the application of power, control etc. differ from one another in the weighting of opportunity - the opportunity of involvement in your own health care contrary to the obligation of involvement (WHO 1998; Rodwell 1996, and Ellis-Stoll/PopkessVawter (1998) in Holmström/Röing 2009; Funnell et al. 1991 in Vásquez 2016). The definitions vary from addressing implicit, obvious actions from the patient (in the WHO and Rodwell definitions, among others (WHO 1998: 354, Rodwell (1996) in Holmström/Röing 2009: 169)) to Funnell's addressing of competences necessary to be able to influence (Funnell et al. (1991) in Vásquez 2016: 910). Olesen ( 2010), however, points out that the evening out of power, control and so on by itself entails a displacement of responsibility (also indicated in Rodwell's definition) and, in that way, an obligation for the patient to act and be involved and take decisions, for instance, if they want successful treatment and care (Olesen 2010).

Paradoxically, this makes patient empowerment not only emancipating, but also a form of governance/management tool just like the concept of empowerment was used in the 80 s (Olesen 2010). 
Similarities and differences between patient empowerment and patient centeredness

If patient empowerment can also be a management tool that obligates the patient to be involved and act (in a certain way), then the concept of empowerment can be considered as being in contrast to patient-centeredness; that is, being in contrast to following the patient's own wishes, needs and possibilities. This is because some patients' needs and wishes can be not to be involved in decisions regarding their health - an often neglected point that Holmström/Röing (2009) do in fact touch upon. (See also Salmon/Hall (2004), who furthermore point to patient surveys which show how the need for control of your own situation can decrease when you become ill).

Generally, the two concepts are considered as two sides of the same coin with many similarities in their definitions. Reviews of literature on patient-centeredness by Mead/Bower have resulted in the defining of five distinct dimensions of the concept (Mead/Bower 2002 in Holmström/Röing 2009: 168). Holmström/Röing conclude that these dimensions may be looked upon as the defining attributes of patient-centeredness (Holmström/Röing 2009: 168). These are: attention to both biological, psychological and social aspects of a person's health; illness as an individual phenomenon; the sharing of power and responsibility between health-care provider and patient as well as a therapeutic alliance between the two; and respect for the individuality of the health-care provider (Mead/Bower 2002 in Holmstöm/Röing 2009: 168).

Thus, an overlap in the definitions of patient-centeredness and empowerment is clear and both concepts are in contrast to earlier perspectives on medicine and, from the point of view of the patient, a great step forward. But the differences are due to the potential conflict between the expected wishes and needs of the patients and the actual ones. In a review of literature on patient-centered care models and research, Bergman/Connaugthon (2013) pointed out that one of the greatest challenges of practising patient-centered care is knowing what is most important to a patient, instead of taking for granted what the patient needs. Naturally, the health care professionals are under a constant obligation to pay attention to what actually makes the patients able to be involved. It may be easy to agree on the nature of empowerment, but no doubt more difficult to fulfil the criteria for empowerment in practice.

In conclusion, patient empowerment is not a way to be patient-centered prior to the patient expressing a wish to take an active part in decision-making. Politically and professionally, it may be possible to find arguments for patient empowerment as a goal in itself. According to Vásquez et al. (2016), for example, it can be justified in terms of ethical considerations, cost controlling, health outcomes, and non-health outcomes. In spite of the fact that the two concepts are often used interchangeably, it is only when empowerment is also the wish of the patient that empowerment can be considered a patient-centered initiative. However, fundamental to empowerment and most cases of patient-centeredness is the requirement that patients are able to read and understand the information about their own health to which they have access, e.g. the e-records.

The present study of the readability of e-records thus attempts to shed light on whether e-records can be an empowering and patient-centered initiative in practice and not only on paper. If we find that e-records are potentially readable and understandable to most patients, it is possible to talk about e-records as a patient empowering initiative. In that case, the next step would be to investigate whether patients wish and need power, control etc., as well as obligations to be involved in their own health-care. If so, access to e-records can rightly be hailed as both an empowering and patient-centered initiative. In the opposite case, it would no longer be reasonable to frame the access to e-records as both empowering and patient-centered and this would be seen as a mere discursive construct.

\subsection{Factors which may affect the readability of Danish e-records}

\section{The Danish health-literacy level}

In a study involving eight EU member states, $47 \%$ of the study population had trouble reading and understanding health information in general, corresponding to a limited functional health-lit- 
eracy level, according to Nutbeam (HLS-EU Consortium 2012, Sørensen et al. 2012). Bo et al. (2014) were the first to explore the health-literacy level of the Danish population using the Australian HLQ-questionnaire. They found that $10-20 \%$ of the population were not able to understand health information sufficiently to know how to act or to interact actively with health-care professionals (Bo et al. 2014). These numbers are problematic if it is taken into consideration that the WHO estimates that health literacy is more important to health condition than income, employment, education, race, and ethnicity (Kickbusch et al. 2013: 7). Thus, a limited health-literacy level is, for example, associated with more risky lifestyle choices, more and longer hospitalisations and a more inexpedient handling of chronic diseases (Kickbusch et al. 2013, ch. 2). Moreover, a Swiss review shows that, on the health system level, the extra expenditure caused by limited health literacy is 3-5\% of the health expenditure in total per year (Eichler et al. 2009: 316-321).

It should be noted that the study merely reports on patients' self-perceived ability to understand, act and interact, a method which may lead to positive bias with patients overestimating their own abilities (a person may believe that information has been understood correctly even if it has not). The study furthermore concludes that a low health-literacy level is subject to a social gradient and is especially noticeable in lower socioeconomic groups, non-ethnic Danes and older people.

To avoid the consequences of a limited health-literacy level mentioned above, it is imperative to adjust written health information for patients to their actual health-literacy level, according to both WHO and Sundhedsstyrelsen (Danish Health Authority; Madsen et al. 2009; Kickbusch et al. 2013: 10). A clear gap between the level of difficulty in Danish written health information as it is written today and the readers' capacities/skills is demonstrated in Madsen et al. (2009: 18), who recommend that texts written for patients should be targeted at the level of $5^{\text {th }}$ or $6^{\text {th }}$ grade $(11-12$ years) no matter who the reader is. In other words, to write to the lowest common denominator, e.g. by using everyday words, short sentences and following certain layout rules (Madsen et al. 2009: 18-19). That is, not the typical expert language which we expect to find in the e-records.

\section{Patient access to Danish e-records - a working tool for health professionals}

A Danish example of health information hailed as a patient-centered and patient empowering initiative is the medical records to which patients have had electronic access since 2010 (sundhed. $\mathrm{dk}$ 2015). Between 1987 and 2010, patients had the right to access hospital records (Vejledning om aktindsigt 1998). However, in practice, patients could orally or in writing request access to their hospital records and retrieve a copy or read it together with a health professional. Further, the patients had the right to get help understanding the information in the records. However, patients did not have to use this right, even though the Health Authority's instruction about access to health information stated that

"it is considered disturbing to hand over a copy of the record to the patient without medical guidance"

(Vejledning om aktindsigt 1998).

Today and since 2010, all Danes over 15 years have online access to their e-records through www. sundhed.dk and to almost all their own hospital data, but not data from the general practitioner. It takes three days from data and notes have been registered at the hospital until they can be shown to the patient in their e-records. The e-records are written by and to health care professionals as a cooperation and communication tool. The records to which the patients have access are exactly the same as those accessed by health care professionals (www.sundhed.dk 2015).

In 2015, five years after the Danes obtained access to their e-records, an evaluation of Sundhed. dk showed that $23 \%$ of the Danish population had read their e-records and $52 \%$ knew about the possibility of reading them (Analyse Danmark 2015). By comparison, a study from 1988 showed how only $0.4 \%$ of the Danish population annually requested access to their hospital records (Andersen/Jørgensen 1988). 


\title{
The effects of reading hospital records
}

Studies show a mixed picture of how patients are influenced by their access to records - electronic as well as on paper. The literature does not agree on subjects such as security, concerns, confidence, insight and communication, as some studies show an increasing and some a decreasing effect of patient access (Sergeant 1986, Short 1986, McLaren 1991, Ross/Lin 2003, Winkelman et al. 2005, Fisher/Windfield 2009, Mcginn et al. 2011, Zurovac et al. 2012, Van Der Vaart et al. 2013, Andrews et al 2014, Giardina et al. 2014, Van der Vaart et al. 2014, Jilka et al. 2015, Mcnamara et al. 2015). To our knowledge, it has never been examined in a Danish context if patients do in fact benefit from accessing and reading their e-records, let alone whether they understand them.

The readers of the e-records are potentially the entire Danish population. Many readers are in a situation that deviates from their normal condition, because they are ill and their situation is thus potentially a more vulnerable one (Hansen 2016: 20-21).

In this study we investigate the records isolated from their contexts. However, besides the above-mentioned we assume that, in reality, the patients often receive other information together with the records, including spoken communication, and to some extent they know their own case before reading the records. This could give the patients some prior knowledge that facilitates the reading of the e-records. Moreover, some may be conscious of the fact that they are reading the working tool of the health-care provider while reading the e-records. Still, the reading situation may well be one of the hardest one can imagine: the patients have no possibility of feedback, the content can have serious consequences for their future, they may be ill and weakened and they have to read online. All in all, it is our assumption that the context will not have a positive impact on the patients' abilities to read their e-records.

In conclusion, if we consider Nutbeam's (2000) theory of health-literacy levels, being able to "read, understand and act on health related information" is a prerequisite for even the lowest level of functional health literacy and true empowerment is not reached before the level of critical health literacy. Because the e-records are the working tool of health professionals (sundhed.dk 2015), we hypothesise that they are written in a language which is not generally accessible to the average patient. If this is true, then it would be highly unlikely that the patients can and will take part in their own health care based on their access to the e-records. The access to their e-records would only create an obligation to take part.

\subsection{Framing access to e-records as a patient-centered and empowering initiative}

In a news document from Danske Regioner (Danish local authorities) framing e-records, the chairman of Danske Regioner, Bent Hansen, substantiates their choice of patient access in the following way:

\begin{abstract}
With the electronic patient records we now give patients the possibility for increased insight into their illness. In this way, we meet a growing need in the population that the health system be more open and transparent for the individual patient (www.regioner.dk 2009)1.
\end{abstract}

In another document on e-record access, Danske Regioner frame it more directly as patient empowerment:

The sharing of knowledge between health professionals and patients and their relatives is an important factor for patient empowerment. When access to health data and health information is easy, the patients' and their relatives' possibilities for gaining more knowledge about illness and treatment are increased [...] (Regionernes Sundheds-IT Organisation 2011: 12). ${ }^{2}$

1 Translated from the Danish original by the authors ("Med de elektroniske patientjournaler giver vi nu patienterne mulighed for at få større indsigt i deres sygdomsforløb. Dermed imødekommer vi et voksende behov i befolkningen om, at sundhedsvæsnet skal være mere åbent og gennemskueligt for den enkelte patient".)

2 Translated by the authors ("Deling af viden mellem sundhedsprofessionelle og patienten og pårørende er en vigtig faktor for patientens empowerment. Når adgang til sundhedsdata og sundhedsinformationer er let, øges patientens og pårørendes muligheder for at blive mere vidende om sygdom og behandling [...]") 
Danske Regioner also link the access to patient-centeredness:

Transparency and easy access to their own data is a prerequisite for placing the citizen at the centre and creates a foundation for patient-centered treatment. [...] Only if the citizens have access to their own data, can they in fact be said to be at the centre and equipped with the information necessary to take an active part in their own treatment (Danske Regioner 2015: 30). ${ }^{3}$

Key words in the statements are "increased insight", "more open", "transparent", "knowledge sharing", "patient empowerment", "easy access", "more knowledge", "patient-centeredness" and "active part in own health". These claims differ from our hypothesis of the e-record not being empowering and patient-centered and we will return to this contradiction in our discussion. As mentioned above, the aim of this study is therefore to examine the language of the e-records in order to determine whether Danish patients are likely to be able to read and understand their e-records. We shall furthermore discuss the possible implications of our results in relation to the discursive construction of e-record access as a patient empowering and patient-centered initiative.

\section{Data and method}

In order to analyse the language of the e-records, 10 Danes were contacted in writing with a view to gaining access to their personal e-records, or those of a person from their network. The persons contacted were not respondents, but solely the providers of access to the data and consent was quickly obtained from all ten. The persons recruited were from the personal network, once or twice removed, of one of the authors, which is deemed to be methodologically sound as the researcher had no possibility of contaminating the data obtained (Hansen 2016: 24-26).

The 10 records analysed an amount of 689 pages in total and records varied in length from 3 to 268 pages. The 10 patients involved, three men and seven women, were between 26 and 69 years of age. They had been treated in three different Danish regions and the reasons for their hospital contact varied greatly.

The data were subjected to a qualitative textual readability/potential lay-friendliness analysis ${ }^{4}$ in order to find out what characterised the language of the records and whether patients were likely to be able to read and understand their records. The focus of the analysis was, as mentioned, on the reader's potential understanding of the text rather than the content. The analysis was structured along the following parameters, inspired by Nord (1991), Helder (2011) and Jensen (2013), who set out analytical parameters for professional, factual texts:

General comments: e.g. layout, spelling, cohesion and coherence

Syntax: e.g. sentence length, density of information, voice, nominalisation and premodification

Lexis: e.g. expert terminology, Latin, abbreviations, euphemisms, personal pronouns and officialese

Stylistic markers: e.g. irony, humour, metaphors, metonymy and analogy.

Some of the parameters are included in all three of the above-mentioned publications and some are only mentioned in one of the publications. They were chosen on the basis of their significant role in regards to the ability of patients to read and understand their records.

To be able to analyse 689 pages, the analysis was carried out in two steps. Firstly, all 689 pages were read and genre characteristics, and illustrative examples of the analytical parametres or other conspicuous phenomena concerning the readability were noted down under the above four headings, resulting in an illustrative analysis. Secondly, certain moves were chosen for a more de-

3 Translated by the authors ("Åbenhed og let adgang til egne data er forudsætningen for at sætte borgeren i centrum og skabe grundlaget for patientcentreret behandling. [...] Kun hvis borgeren har adgang til egne data, kan borgeren reelt siges at være i centrum og udstyret med de oplysninger, der er nødvendige for at kunne tage aktiv del i eget behandlingsforløb")

4 In this article, we use readability and potential lay-friendliness interchangeably. 
tailed analysis, namely the moves which deal with plans for the future. If access to e-records is to boost patient empowerment, it is crucial that the patients understand the parts of the records which describe specifically whether the patient needs to act on something or behave in a certain way in future. These moves amounted to a total of 23 pages for all 10 records and these pages were analysed in detail in accordance with the parametres listed above, as well as the parametres identified in the first step of the analysis. The analyses reported on in this article are the combined results of the two analyses. They are qualitative in nature, with a quantitative element in the sense that frequency has not been statistically calculated, but is commented upon when a tendency is clear. For example, "the abbreviation 'pt.' is only spelled out once in the 689 pages".

\section{Results}

As mentioned above, the analyses seek to characterise the language of the e-records with a view to determining potential readability for patients. Extratextually, it should be noted that when accessing records, it is fairly common to receive information from the system about technical errors which mean that some documents relevant for a particular set of records cannot be accessed. This may potentially damage the coherence of the records. Following are the most characteristic findings of the two analyses, together with their potential influence on lay-friendliness.

\subsection{General comments}

The sheer length of the records is likely to contribute negatively to readability. The longest records consisted of 268 pages, which is a rather large number of pages to navigate, especially if the patient in question is not a strong reader (Dickinson et al. 2001: 154, Askehave/Zethsen 2000a: 38). Much information is simply not relevant for the patient and the level of redundancy is high. Generally, the e-records have a clear and logical structure, which is likely to have a positive influence on lay-friendliness (Keselman et al. 2007: 402, Jensen 2013: 99-102, Dickinson et al. 2001: 156). However, the many headlines are dominated by expert language and the headlines do not always cover the actual content of the section:

\footnotetext{
Headline: "Diætistnotat:" [Note from dietitian]

Text: "Der måles håndgribestyrke, der viser at pt.s håndgribestyrke er $68 \%$ af referenceværdien." [hand grip strength is measured which shows that the patient's hand grip strength is $68 \%$ of the reference value]
}

The records are furthermore characterised by numerous linguistic errors, typically spelling mistakes which could, in some cases, result in comprehension problems (Jensen 2013: 117-118, Göpferich 2009: 42-43). Use of a particular font or pitch is not consistent; neither is the use of capital letters and punctuation. This could potentially confuse the patient as it is, for example, difficult to assess which passages should be emphasised (Jensen 2013: 112-113, Göpferich 2009: 40-42).

There are thus, in general, both elements which could have a negative impact on comprehension and elements which aid readability. Even though the structure is far from perfect it is under this parameter that most positive features are found in the analyses.

\subsection{Syntax}

\section{Sentence length}

Sentences are mostly either very long or very short, consisting of one word only. Long sentences are not necessarily problematic from a readability point of view, but when coupled with other expert features, the typically long and complex sentences must be presumed to hamper understanding. When sentences become very long (there are examples of seven-line sentences in the 
records), they are likely to be problematic solely on the grounds of the amount of information included. As regards the very short sentences, they are in fact typical for expert language as well:

"håndkøbsmedicin" [over-the-counter medicine]

The reader needs to be able to interpret this compound noun which forms a one-word sentence (Jensen 2013: 66-88, Askehave/Zethsen 2000b: 71-72). In this case, the context shows that the patient can be treated for pain with over-the-counter medication instead of prescription painkillers.

\section{Voice}

The passive voice is the norm in the e-records, thus making it harder for the reader to find out who the agent is (Jensen 2013: 48-52, Göpferich 2009: 46-48, Askehave/Zethsen 2000b: 71-73):

"Der skal holdes gang i maven" [the stomach should be kept in working order]

It is not evident who is in charge of this task.

\section{Nominalisations}

The records contain many nominalisations which, like the passive voice, hide the agent of the sentence. Nominalisations are not necessarily problematic if they are commonly used in ordinary language, but when they are infrequent, and even sound rather artificial to the non-expert as is the case in the records, they are typically harder to process:

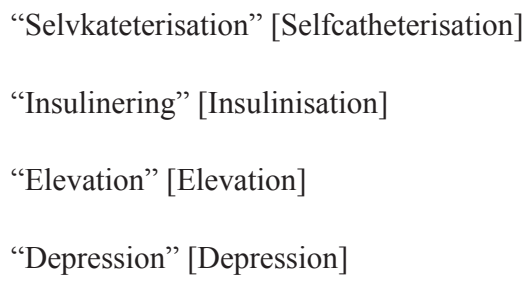

The two latter examples are in the context of elevation or depression of the shoulder. These nominalisations are not common in Danish and especially "depression" may be confused with the common noun denoting a mental illness.

\section{Premodification}

The e-records contain a very large number of premodifications. These can be challenging to most lay readers as it is often difficult to be sure what modifies what when expert knowledge is not present. The Danish language exacerbates the problem because of an orthographic tendency to write words together (Jensen 2013: 63-64, Askehave/Zethsen 2000b: 72-73):

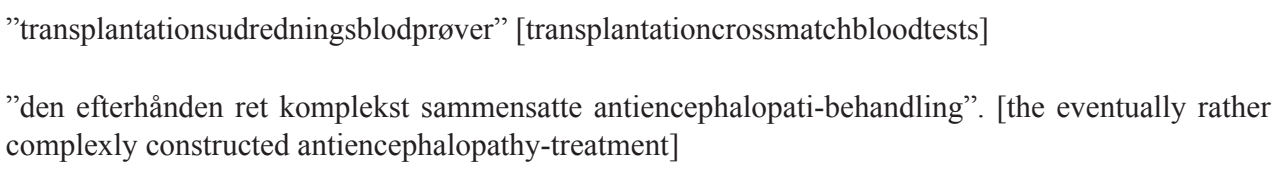

Adding to the complexity is the fact that the premodifications themselves often contain other expert language characteristics such as expert terms, nominalisations and officialese.

\section{Ellipsis}

Especially in the moves about future plans, ellipsis is very common and sentences are short and condensed: 
It is thus up to the patients to guess the verbs and pronouns left out.

\subsection{Lexis}

\section{Expert terminology}

Practically all sentences in the e-records are dominated by expert terminology mostly of Latin/ Greek origin. In contrast to English, medical Danish often has a Latin-based expert term and a Danish lay term for the same phenomenon (appendicitis is, for example, called appendicitis in Danish expert language, but blindtarmsbetcendelse when mentioned in layman terms. The expert term is simply never used by non-experts. This means that Danes in general do not have the same Latin-based medical vocabulary as English-speaking people (Zethsen 2004: 125-142, Askehave/ Zethsen 2000b: 69-70). These are just a few of the many examples of expert terminology:

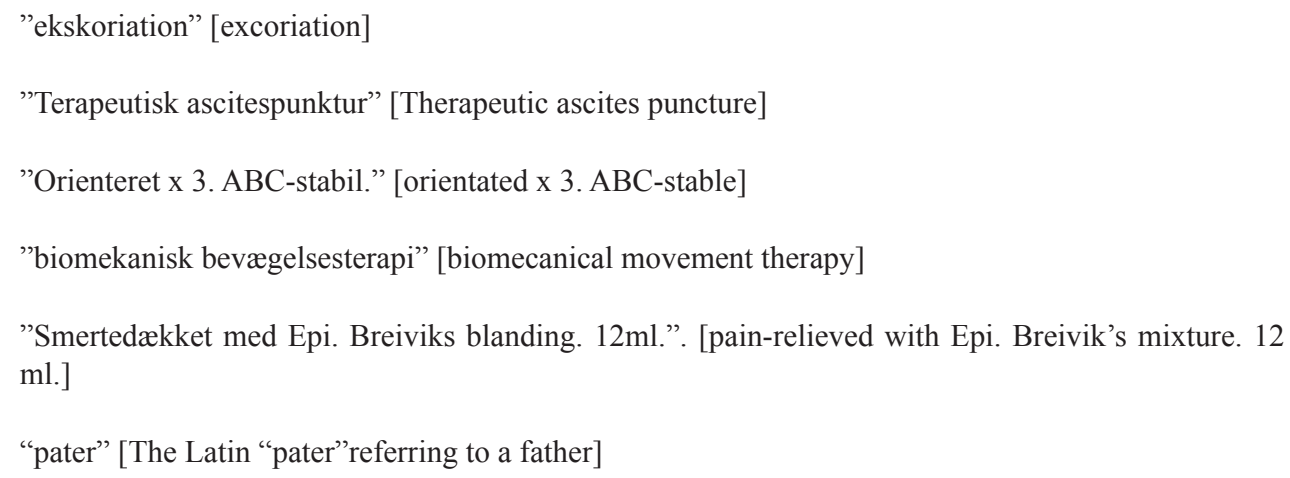

\section{Common expressions with an expert meaning}

Another example of the use of expert terminology is when "ordinary" Danish words are used with an expert meaning thus creating "false friends" (Jensen, 2013: 59, Askehave/Zethsen 2000a: 31, Helder 2011: 149-150, Askehave/Zethsen 2000b: 70):

"Positiv"/"negativ" [positive/negative]

Within medical jargon, the fact that a test is positive is often not good news and vice versa, which is the opposite of the everyday usage of the words.

"Patienten skal derfor fortsat behandles konservativt." [Thus the patient should still be treated conservatively]

"Conservatively" would for most Danes have political connotations.

"biomekanisk bevagelsesterapi" [biomechanical movement therapy]

The word 'therapy' has clear psychological connotations in Danish and is not usually applied to any form of physical treatment.

"Dettes gøres under doekke af $10 \mathrm{ml}$ lidokain." [this is done under cover of $10 \mathrm{ml}$ lidokain]

It simply informs the reader of the anaesthetic used, but to the non-expert it sounds rather dubious. Generally speaking, very few examples or analogies are used to explain the expert content of the records. The text is much more abstract than concrete, which is especially problematic in the moves which set out plans for the future - plans which may actively involve the patient (Jensen 2013: 65-66 and 85-87). 


\section{Abbreviations and unexplained numbers}

The many abbreviations in the e-records may cause readability problems as the reader is unable to decipher them (Short 1986: 1317, Bhavnani et al. 2010: 3, Göpferich 2009: 46-47):

\footnotetext{
"Rp. kolpo om 4 mdr.". [the three abbreviations here mean "recipie colposcopy in 4 months"]

"CS" [The abbreviation "CS" stands for the English term "cervical screening" which is an added complication. The English expression is very likely not understandable to most Danes even if they were able to write out the abbreviation]

"Pt."["patient" is abbreviated to "pt." which in ordinary Danish is the abbreviation for the Latin expression "pro tempore" meaning "for the time being". Only once in 689 pages is "patient" spelled out.
}

Numbers are rarely explained and may therefore be nonsensical to patients. An exception is the following example (Keselman et al. 2007: 402, Jensen 2013: 85-88):

"Pt.s HbAlc er 57, og det er også ganske fint for en diabetespt." [Pt's HbAlc is 57, and this is actually quite good for a diabetes patient]

In the above example, the number is interpreted and translated, which makes it accessible to the patient.

\section{Officialese}

Officialese may be known by patients from other contexts and may be understandable to some patients. However, patients who are not strong readers may find the writing style inaccessible. Whether it is understandable or not, it distances the patient from the writer and the communication becomes very formal and impersonal (Jensen 2013: 47-49, Bjerre 2011: 99-103, Askehave/ Zethsen 2000a: 32).

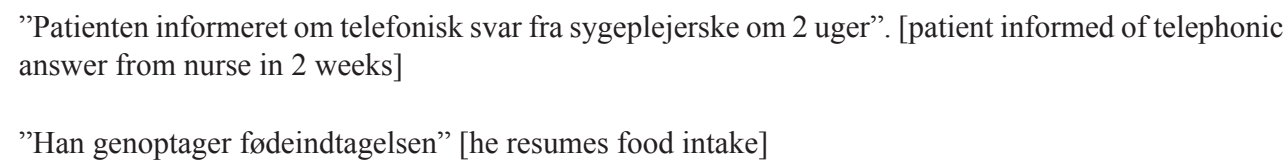

\section{$\underline{\text { Synonymy }}$}

Synonymy, especially in the form of using both the Latin and the Danish terminology interchangeably and in the form of inconsistent abbreviations, is common in the records:

"Hernie/brok" [hernia from Latin and layman Danish, respectively]

BS/blods. [blood sugar, two different abbreviations]

Synonymy is generally not advised in texts directed at lay people as the phenomenon is likely to create confusion. The layperson may simply not know that two expressions stand for the same, as in the case with the two expressions for "hernia", and they may assume that a second condition is involved (Jensen 2013: 56-62, Askehave/Zethsen 2010: 106).

\section{Presupposition}

Expert terminology, abbreviations, unexplained numbers in themselves involve the presupposition that the reader is familiar with the terms and expressions and will understand the content. Otherwise the communication would be meaningless. However, there is also another kind of presupposition in the e-records involving expressions which are not difficult to understand as such, but where the lay reader may not know what the expressions entail (Jensen 2013: 64-66):

"Vi tager nye blodprøver i dag, for at se om han er på vej den forkerte vej.". [we will take new blood samples today to see if he is taking the wrong direction] 
In this example, the reader may not know what "the wrong direction" actually indicates.

"Forslag til evt. yderligere udredning og behandling: - Knoglevenlig livsstil." [Proposal for possible further investigation and treatment: - bone-friendly lifestyle]

In this example, it is presupposed that the reader knows what a "bone-friendly lifestyle" entails.

"Henvist [til gynækologisk ambulatorium] fra egen læge pga ASCUS. Kendt med psoriasis." [Re-

ferred [to gynecological outpatient clinic] from own doctor due to ASCUS. Known with psoriasis.]

In this rather complex example, it is presupposed that the reader understands the abbreviation ASCUS (a form of abnormal cells), but also the medical connection between the presence of abnormal cells in the cervix and the skin disease psoriasis.

\section{Pronouns}

These are frequently left out with the same effect as the passive voice and nominalisation. The agent is hidden and the sentence becomes more impersonal (Göpferich 2009: 43-44, Askehave/ Zethsen 2000b: 71-72):

"Må tage frit per os og supplere med Glucose 20\% $35 \mathrm{ml} /$ time." [Can take freely per os and supplement with Glucose $20 \% 35 \mathrm{ml} /$ hour]

\subsection{Stylistic markers}

In connection with the e-records, stylistic markers are notable through their absence. There are a few metaphors like:

"Vi giver alt hvad vi har i skuffen imod encefalopati." [we give everything we have in the drawer against encefalopati]

but generally the text is very formal and does not contain metaphors, wordplay, and so on. This absence is of course characteristic for expert language, though metaphors and analogies could be used to make difficult content more accessible to the layman reader.

The text is not characterised by euphemisms with the exception of the mention of bodily functions. In the cases where the euphemism is created by means of Latin:

"faeces" [faeces]

It may not be understood by the average patient, whereas the euphemisms which make use of everyday expressions are much easier for the patient to understand (Jensen 2013: 61-62):

"der er gang i maven" [the stomach is working]

\section{Discussion and conclusion}

As appears from the above analysis, the e-records are without doubt written in highly specialised expert language dominated by expert terminology, expert syntax, expert presuppositions, difficult abbreviations, and so on. This comes as no surprise as the records are the everyday working tool of the medical professionals, but it is the first time in a Danish context that the linguistic nature of the e-record discourse has been documented. Considering the health-literacy levels of the Danish population in general, it seems highly unlikely that all Danes would understand their e-records. A reasonable hypothesis would even be that the majority of Danes will not fully understand their own e-records and will have a high potential for misunderstandings. This might lead to confusion, insecurity, unnecessary fear ${ }^{5}$, and lack of appropriate action: in short, not to increased

5 In this article we focus on the linguistic aspects of the e-records in our analyses. Another relevant dimension would be risk communication. Expert perception and communication of risk may be very different from those of laymen: for example, a doctor may write about a suspicion of cancer even though he deems the risk to be less than 5\%. The patient, 
empowerment and/or patient centeredness. Some patients may of course be able to read and understand their e-records and benefit from the information they gain, and some may be inspired to discuss aspects with their doctor and thus gain new insights, but we believe that the language of the e-records is so complex that the majority of Danes will not benefit from access. According to Nutbeam (2000), even the lowest level of his health-literacy continuum, functional health literacy, requires the patient to be able to basically read, understand and act on health related information. True empowerment cannot take place unless the patients have critical health literacy, which allows them to critically evaluate health information and use the information to take control of their own health, illness and living conditions. It may be utopian that all members of a society can gain critical health literacy and thus true empowerment in Nutbeam's understanding. However, it seems a fair requirement that all patients should be able to read and understand information made available to them about their own health. If this is not the case, we find the claim that increased empowerment takes place very questionable. If we return to the statements from the Danish local authorities it is quite clear that by introducing the new access to e-records with expressions such as "increased insight", "knowledge" and "knowledge sharing", "openness", "transparency", "easy access", an "active part in [their] own health", the notions of "patient empowerment" and "patient-centeredness" are presumed. It seems to us that the Danish local authorities confuse "easy access" electronically with real access: that is, when patients actually can read and understand the information provided. In the same way, the Danish local authorities seem to disregard the fact that empowering e-records would only be patient-centered if patients actually want to be involved in all details of their illnesses and treatment. Thus, completely open electronic patient access to the "raw" records, so to speak, may in fact be a far cry from a truly patient-centered initiative.

Patients are clearly not the primary target group of the e-records, but the question remains why access to e-records is discursively constructed as a patient centered and patient empowering initiative. At the moment, we can only provide qualified guesses. Possible answers may involve meeting pressure from resourceful patient groups, political correctness (providing access to unfiltered information in the name of transparency may seem to be the acceptable thing to do), or a kind of disclaimer (patients cannot claim that they did not know giving them a responsibility to act themselves if something is wrong), and thus empowerment seems to be used as a form of governance knowingly or unknowingly. A more positive answer would be that politicians at the Danske Regioner hold a genuine desire to share information and create patient empowerment, but that they lack awareness of the nature of the e-records and are ignorant of the fact that access is not necessarily the same as successful communication ${ }^{6}$.

Giving patients access to a document they are, in many cases, most likely not able to read and understand; and, in addition, framing this as empowerment, may lead to patients not being able to meet their obligations (as stated by Olesen (2010). Furthermore, this may lead to the Danish local authorities disregarding the fact that patients need more help to get involved in their care and treatment. According to Olesen (2010), the health-care system can "shift the responsibility for the individual patients as they themselves become responsible partakers in their own treatment", which he characterises as "empowerment on the terms of the health-care system" - as opposed to being on the terms of the patient.

The conclusions of this article have been drawn on the basis of e-records seen in isolation. In reality, we assume that patients often receive other information together with the records, including spoken communication, and, to some extent, they know their own case before reading the records. In contrast, the reading situation may well be one of the hardest one can imagine: the patients have no possibility of feedback, the content can have serious consequences for their future,

when reading about the suspicion, may think of the risk as much higher.

6 For a more detailed discussion see Zethsen (2018).

7 Translated by the authors ("kaste en del af ansvaret for de enkelte patienter af sig, da disse nu selv er ansvarlige parthavere i sygdommens forløb...empowerment på sundhedssystemets præmisser") 
they may be ill and weakened and they have to read online. As for the validity of our results we can say that we - as highly educated readers - have analysed 689 pages of e-records without even being close to understanding all of the content.

\section{Practice implications and future studies}

Some patients may benefit from access to their e-records but, based on the present study, we fear that access for everyone is a misguided course of action more than a patient-centered initiative, and would recommend the authorities to withdraw the initiative/re-consider the policy. We are aware that this would be a difficult political decision and would require reception studies showing a harmful effect on patients, but as it is now we find it hard to believe that access to these expert texts is an advantage to most Danes. We believe that there is a large potential for a negative psychological effect on many patients. In particular, the time which is likely to pass between reading the e-records and the possibility of talking to a health professional is a cause for worry. Apart from the problems of simply (mis)understanding the e-records and the risk of confusion and perhaps fear, there is a psychological aspect which has not been investigated. What is the effect on patients of reading a sometimes very large, and perhaps overwhelming, number of pages and a large number of details about their illnesses? Is openness and transparency always the same as patientcenteredness (even in cases when the information offered is fully understandable to the patient)?

In our study, we have seen the e-records from the patient's perspective, though we have not tested how much patients do in fact understand. This would be an interesting study, perhaps with the aim of finding out which phenomena most hamper understanding. Another important perspective is that of the medical professionals. It could be hypothesised that the open access has had a negative effect on the way they communicate with each other freely and directly. This was supported by the results of a recent master thesis at Aarhus University by Anders Jensen (2017).

His study, which was based on 12 semi-structured interviews with hospital doctors, concluded that the doctors found that electronic patient access had put constraints on their expert-to expert working tool. Their main concerns were that patients may be offended by (and perhaps complain about) the direct tone they use for practical and efficient purposes. They were afraid to vent hypotheses for diagnostic purposes in order not to scare the patient and therefore sometimes deliberately camouflaged with complex expert language to ensure that the patient did NOT understand. In general, they considered patients as not understanding and therefore deplored the fact that patients read and misunderstand their records before they have had a chance to talk with a doctor.

We cannot recommend access for all as long as the main purpose of the e-records is to be a working tool for health professionals. Our recommendation, instead of full access for everyone, would be to allow the possibility to apply for access, as was the case before the records became electronic. If access is granted, it should automatically be coupled with a meeting with a health professional who can explain the content and answer the patient's questions, but this is of course a question of resources. We know these solutions may well go against the political correctness of our time, which often requires complete transparency, but hope that the patient's well-being will eventually become more important.

\section{References}

Analyse Danmark 2015: Evaluering af sundhed.dk [online]. https://www.sundhed.dk (accessed 20 September 2015, no longer available).

Andersen, Teis/Jørgensen, Georg 1988: Danish Experience of statutory right of patients to access hospital record. In The Lancet 2, 1428. doi: https://doi.org/10.1016/S0140-6736(88)90621-6.

Andrews, Lynda/Gajanayake, Randike/Sahama, Tony 2014: The Australian general public's perceptions of having a personally controlled electronic health record (PCEHR). In International Journal of Medical Informatics 83, 889900. doi: http://dx.doi.org/10.1016/j.ijmedinf.2014.08.002.

Askehave, Inger/Zethsen, Karen Korning 2000a: The Patient Package Insert of the Future (report for The Ministry of Health). Aarhus: Aarhus School of Business, Det erhvervssproglige fakultet. 
Askehave, Inger/Zethsen, Karen Korning 2000b: Medical Texts Made Simple: Dream or Reality? In Hermes - Journal of Language and Communication Studies 25, 63-74.

Askehave Inger/Zethsen, Karen Korning 2010: PIL of the month: A study of best practice in EU patient information leaflets. Journal of Applied Linguistics and Professional Practice 7, 97-120. doi: 10.1558/japl.v7i1.97.

Bergman, Alicia A./Connaugthon, Stacey L. 2013: What is Patient-Centered Care Really? Voices of Hispanic Prenatal Patients. In Health Communication, 28, 789-799. doi: 10.1080/10410236.2012.725124

Bhavnani, Vanita/Fisher, Brian/Winfield, Marlene/Seed, Paul 2010: How patients use access to their electronic GP record - a quantitative study. In Family Practice International Journal 0, 1-7. doi: 10.1093/fampra/cmq092.

Bjerre, Malene 2011: Mød din kunde - guide til effektiv kommunikation, 99-103. Copenhagen: Gyldendal Business.

Bo, Anne/Friis, Karina/Osborne, Richard/Maindal, Helle T. 2014: National indicators of health literacy: ability to understand health information to engage actively with health-care providers - a population-based survey among Danish adults. In Biomed Central Ltd. 14, 1095-1106. doi: 10.1186/1471-2458-14-1095.

Cornwall, Andrea/Brock, Karen 2006: What do buzzwords do for development policy? a critical look at "participation", "empowerment" and "poverty reduction". In Third World Quarterly 26, 1043-1060. doi: $10.1080 / 01436590500235603$.

Danske Regioner 2015: Sundhedsdata i spil - en politik om hvordan sundhedsdata kan gøre gavn. Copenhagen: Danske Regioner.

Dickinson, David/Raynor, David/Duman, Mark 2001: Patient information leaflets for medicines: using consumer testing to determine the most effective design. In Patient Education Counselling 43, 147-159. doi: 10.1016/S07383991(00)00156-7.

Eichler, Klaus/Wieser, Simon/Brügger, Urs 2009: The costs of limited health literacy: a systematic review. In International Journal of Public Health 54, 313-324. doi: 10.1007/s00038-009-0058-2.

Ellis-Stoll, Cynthia C./Popkess-Vawter, Sue 1998: A Concept Analysis on the Process of Empowerment. Advances in Nursing Science 21, 62-68.

Fisher, Brian/Bhavnani, Vanita/Windfield, Marlene 2009: How patients use access to their full health records: a qualitative study of patients in general practice. In Journal of the Royal Society of Medicine 102, 539-544. doi: 10.1258/ jrsm.2009.090328.

Funnell, Martha M./Anderson, Robert M./Arnold, Marylinn S./Barr, Patricia A./ Donnelly, Michael/Johnson, Patricia D./Taylor-Moon, Denise/White, Neil H. 1991: Empowerment: An Idea Whose Time Has Come in Diabetes Education. The Diabetes Educator 17, 37-41. doi: 10.1177/014572179101700108.

Giardina, Traber D./Menon, Shailaja/Parrish, Danielle E./Sittig, Dean F./Singh, Hardeep 2014: Patient access to medical records and health-care outcomes: a systematic review. In Journal of the American Medical Informatics Association 21, 737-741. doi: 10.1136/amiajnl-2013-002239.

Göpferich, Susanne 2009: Comprehensibility assessment using the Karlsruhe Comprehensibility Concept. In The Journal of Specialized Translation 11, 31-53.

Hansen, Martha Monrad 2016: Patientjournal eller patientens journal? En undersøgelse af sproget i e-journal og dets betydning for patient empowerment. Unpublished master thesis, Aarhus University.

Helder, Bodil 2011: Textual Analysis: An Approach to Analysing Professional Texts. Frederiksberg: Samfundslitteratur.

HLS-EU Consortium 2012: Comparative report on health literacy in eight EU member states. The European Health Literacy Survey HLS-EU. Maastricht: HLS-EU Consortium.

Holmström, Inger/Röing, Marta 2009: The relation between patient-centeredness and patient empowerment: A discussion on concepts. In Patient Education and Counseling 79, 167-172. doi: 10.1016/j.pec.2009.08.008.

Jensen, Anders 2017: Loegen og patientjournalen. Unpublished master thesis, Aarhus University.

Jensen, Leif Becker 2013: På patientens prcemisser. Frederiksberg: Samfundslitteratur.

Jilka, Sagar R./Callahan, Ryan/Sevdalis, Nick/Mayer, Erik K./Darzi, Ara 2015: "Nothing About Me Without Me": An Interpretative Review of Patient Accessible Electronic Health Records. In Journal of medical internet research 17, e161.

Keselman, Alla/Slaughter, Laura/Arnott-Smith, Catherine/Kim, Hyeoneui/Divita, Guy/Browne, Allen/Tsai, Christopher/ Zeng-Treitler, Qing 2007: Towards Consumer-Friendly PHR's: Patients' Experience with Reviewing the Health Records. In Journal of the American Medical Informatics Association 11, 399-403.

Kickbusch. Ilona/Pelikan, Jürgen M./Apfel, Franklin/Tsouros, Agis D. 2013: Health literacy: The solid facts. Copenhagen: World Health Organisation.

Madsen, Marie H./Højgaard, Betina/Albæk, Jens 2009: Health literacy - Begrebet, konsekvenser og mulige interventioner. Copenhagen: Sundhedsstyrelsen 
Mcginn, Carrie A./ Grenier, Sonya/Duplantie, Julie/Shaw, Nicola/Sicotte, Claude/Mathieu, Luc/Leduc, Yvan/Légaré, France/Gagnon, Marie-Pierre 2011: Comparison of user groups' perspectives of barriers and facilitators to implementing electronic health records: a systematic review. In Biomed Central Ltd. 9, 46. doi: 10.1186/1741-7015-9-46.

McLaren, Paul 1991: The right to know: Patients' records should be understandable by patients, too. In British Medical Journal 303, 937-938.

McNamara, Mary/Arnold, Corey/ Sarma, Karthik/ Aberle, Denise/ Garon., Edward/ \& Bui, Alex A.T. 2015: Patient Portal Preferences: Perspectives on Imaging Information. In Journal of the Association for Information Science and Technology 66, 1606-1615. doi: 10.1002/asi.23269.

Mead, Nicola/Bower, Peter 2002: Patient-centred consultations and outcomes in primary care: a review of the literature. In Patient Education \& Counseling 48, 51-61. doi: 10.1016/S0738-3991(02)00099-X.

Nord, Christiane 1991: Text analysis in translation: Theory, methodology and didactic application of a model for translation-oriented text analysis. Amsterdam - New York, NY: Rodopi.

Nutbeam, Don 2000: Health literacy as a public health goal: a challenge for contemporary health education and communication strategies into the $21^{\text {st }}$ century contemporary health. In Health Promotion International 15, 259-267. doi: 10.1093/heapro/15.3.259.

Olesen, Finn 2010: Den forstærkede patient. Om patientbegreber og empowerment. In Thorgaard, Keld/Nissen, Morten/ Jensen, Uffe Juul (eds.), Viden, virkning og virke. Frederiksberg: Roskilde Universitetsforlag, 307-332.

Rappaport, Julian 1987: Terms of empowerment/exemplars of prevention: Toward a theory for community psychology. American Journal of Community Psychology, 15, 121-148. doi: 10.1007/BF00919275.

Regionernes Sundheds-IT (RSI) 2011: Strategi for IT-understøttelse af Patient Empowerment - for et trygt, sikkert og effektivt sundhedsvoesen. Copenhagen: Regionernes Sundheds-IT.

Rodwell, Christine M. 1996: An Analysis of the concept of empowerment. In Journal of Advanced Nursing 23, 305313. doi: 10.1111/j.1365-2648.1996.tb02672.x.

Ross, Stephen E./ Lin, Chen-Tan 2003: The Effects of Promoting Patient Access to Medical Records: A Review. In Journal of the American Medical Informatics Association 10, 129-138. doi: 10.1197/jamia.M1147.

Salmon, Peter/ Hall, George M. 2004: Patient Empowerment or the emperor's new clothes. In Journal of the Royal Society of Medicine 97, 53-56.

Sergeant, Howard 1986: Should psychiatric patients be granted access to their hospital records? In The Lancet 2, 13221325. doi: 10.1016/S0140-6736(86)91445-5.

Short, David 1986: Some consequences of granting patients access to consultants' records. In The Lancet 1, 1316-1318. doi: 10.1016/S0140-6736(86)91232-8.

Strunck, Jeanne/ Askehave, Inger/ Lassen, Inger/ Holmgreen, Lise-Lotte 2010: At styrke patienten i en New Public Management verden: En udredning af betydningspotentialet i begrebet patient empowerment. In Horsbøl, Anders/ Sørensen, Mariann Bjerregaard (eds.), Sundhedskommunikation på sygehuset. Aalborg: Aalborg Universitetsforlag, 147-181.

Sundhedsstyrelsen 2005: Terminologi: Forebyggelse, sundhedsfremme og folkesundhed. København: Sundhedsstyrelsen.

Sørensen, Kristine/ Van den Broucke, Stephan/ Fullam, James/ Doyle, Gerardine/ Pelikan, Jürgen/ Slonska, Zofia/ Brand, Helmut and (HLS-EU) Consortium Health Literacy Project European 2012: Health literacy and public health: a systematic review and integration of definitions and models. In Biomed Central Ltd 12, 80. doi: 10.1186/14712458-12-80.

van der Vaart, Rosalie/ Drossaert, Constance H.C./ Taal, Erik/van de Laar, Mart A.F.J. 2013: Giving rheumatology patients online home access to their electronic medical record (EMR): advantages, drawbacks and preconditions according to care providers. In Rheumatology International 33, 2405-2410. doi: 10.1007/s00296-012-2408-2.

van Der Vaart, Rosalie/ Drossaert, Constance H.C./ Taal, Erik/ Drossaers-Bakker, K Wiepke/ Vonkeman, Harald E./ van de Laar, Mart A.F.J. 2014: Impact of patient-accessible electronic medical records in rheumatology: use, satisfaction and effects on empowerment among patients. In BMC Musculoskeletal Disorders 15, 102. doi: 10.1186/1471-247415-102.

Vásquez, Ana S./ Del Rio Lanza, Ana B./ Álvarez, Leticia S./ Casielles, Rodolfo V. 2016: Empower me? Yes, Please, But in My Way: Different Patterns of Experiencing Empowerment in Patients with Chronic Conditions. In Health Communication,1-6. doi: 10.1080/10410236.2016.1196409.

Vejledning om aktindsigt m.v. i helbredsoplysninger - Sundhedsministeriets vejledning nr. 155 af 14/9 1998 (1998) [online]. https://www.retsinformation.dk/Forms/R0710.aspx?id=21078 (accessed 2 April 2018).

World Health Organisation 1998: Health Promotion Glossary. Geneva: World Health Organisation. 
Winkelman, Warren J./ Leonard, Kevin J./ Rossos, Peter G. 2005: Patient-Perceived Usefulness of Online Electronic Medical Records: Employing Grounded Theory in the Development of Information and Communication Technologies for Use by Patients Living with Chronic Illness. In Journal of the American Medical Informatics Association 12, 306-314. doi: 10.1197/jamia.M1712.

www.regioner.dk. 2009: [online]. http://www.regioner.dk/services/nyheder (accessed 27 October 2017).

www.sundhed.dk. 2015: [online]. https://www.sundhed.dk (accessed 27 October 2017).

Zethsen, Karen Korning 2004: Latin-based terms: True or false friends? In Target 16, 125-142. doi: 10.1075/ target.16.1.07zet.

Zethsen, Karen Korning 2018:_Access is not the same as understanding. Why intralingual translation is crucial in a world of information overload. In Across Languages and Cultures 19(1), 79-98.

Zurovac, Jelena/ Dale, Stacy/ Kovac, Martha 2012: Perceptions of Electronic Health Records and Their Effect on the Quality of Care: Results from a Survey of Patients in Four States. Princeton, NJ: Mathematica Policy Research. 